\title{
Induction of Growth Hormone Release by Dioscin from Dioscorea batatas DECNE
}

\author{
Ho Young Lee, Dae Young Jung', Hyekyung Ha ${ }^{1}$, Kun-Ho Son ${ }^{2}$, Su-Jin Jeon ${ }^{2}$ and Chungsook Kim ${ }^{1, *}$ \\ ${ }^{1}$ Department of Drug Research \& Development, Korea Institute of Oriental Medicine, Daejeon 305-811, Korea \\ ${ }^{2}$ Department of Food and Nutrition, Andong National University, Andong 760-749, Korea
}

Received 22 February 2007, Accepted 8 August 2007

\begin{abstract}
In this study, dioscin was isolated from Dioscoreae Rhizoma (DR), which is the rhizome of Dioscorea batatas DECNE. that inhabits broad areas of Korea and Japan. To determine whether dioscin induced growth hormone (GH) release, we evaluated its induction effects on $\mathrm{GH}$ release both in vitro and in vivo. The $70 \%$ methanol extract of $D R$, and its $\boldsymbol{n}$-hexane and $\boldsymbol{n}$-BuOH fractions, induced rat $\mathbf{G H}$ (rGH) release in rat pituitary cells 10-fold, 8-fold, and 5fold higher than the control $(0.36 \pm 0.02 \mathrm{nM})$, respectively $(p<0.05$ each). The dioscin-induced rGH release of the cells was concentration-dependent and its $\mathrm{ED}_{50}$ was $1.14 \times$ $10^{-5} \mathrm{M}$. Within 90 minutes after intravenous administration of $10 \mu \mathrm{g} / \mathrm{kg}\left(p<0.05\right.$ at $\left.t_{\text {max }}\right)$, dioscin caused the greatest increase in $\mathbf{r G H}$ concentration $\left(\mathrm{C}_{\max }\right)$ in the rat plasma $(34.16 \pm 14.10 \mathrm{ng} / \mathrm{ml})(\mathrm{n}=4)$, which was twice as high as the control group $(12.88 \pm 3.29 \mathrm{ng} / \mathrm{ml})(\mathrm{n}=27)$.
\end{abstract}

Keywords: Dioscin, Dioscoreae rhizoma, Growth hormone (GH), Rat pituitary cells

\section{Introduction}

Growth hormone $(\mathrm{GH})$ is a peptide hormone secreted from the pituitary of animals, and consists of 191 amino acids with a molecular weight of $22 \mathrm{kD}$. GH release is regulated by $\mathrm{GH}-$ releasing hormones (GHRH or GRF) and somatotropin-release inhibiting factor (SRIF). In particular, it is regulated by neurotransmitters or neuropeptides such as serotonin, dopamine, calcitonin, neuropeptide Y (NPY), etc. (Argente et al., 1996).

Additionally, ghrelin (Kojima et al., 1999), which is secreted from the stomach, is identified as a natural ligand of the GH secretagogue (GHS) receptor. GH is used to treat dwarfism and various diseases such as obesity and osteoporosis, and is also used for anti-aging (Horber et al., 1990) because it was found to inhibit protein loss and delay the aging process during middle- and old-age. GHSs (Bowers et al., 1981) are widely classified into sub-groups of peptides (Bowers et al., 1984), including partial peptides (Momany and Bowers, 1996), nonpeptide, and peptidemimetics (Cheng et al., 1993). Also, there are the orally administered L-629, 429, and L-163, 191 (Smith et al., 1993; Patchett et al., 1995) that are under clinical trials.

Dioscorea batatas DECNE. (Dioscoreaceae) grows extensively on mountains as well as in fields within Korea and Japan. Its rhizomes (Dioscoreae Rhizoma; DR) are traditionally used to treat coronary artery disorder or disease caused by blood clotting ( $\mathrm{Au}$ et al., 2004), and are also known to improve immunity (Choi et al., 2003), have antioxidant properties (Farombi et al., 1999; Choi et al., 2002), and decrease blood glucose levels (Brakohiapa et al., 1997; Morrison et al., 2006).

Dioscin, a common component of Dioscorea batatas DECNE. and Polygonatum odoratum D., was isolated and purified from the $\mathrm{BuOH}$ fraction of the DR extract, and its structure was identified, as described before (Kim et al., 1989). Dioscin is known to inhibit the growth of leukemia cells (Wang et al., 2001), has antifungal activity (Sata et al., 1998), and has efficacy as an antineoplastic agent, an immunomodulator, and an anticarcinomic agent (Chiang et al., 1992; Hu et al., 1996). Yet, no one has reported on the use of dioscin in the treatment of various diseases caused by $\mathrm{GH}$ deficiency.

In this study, the herbal medicine Dioscoreae Rhizoma, which is capable of inducing $\mathrm{GH}$, was selected from natural products, and its fractions and components abilities for inducing $\mathrm{GH}$ release were examined.

*To whom correspondence should be addressed.

Tel: 82-42-868-9553; Fax: 82-42-864-2120

E-mail: kim.chungsook@gmail.com 


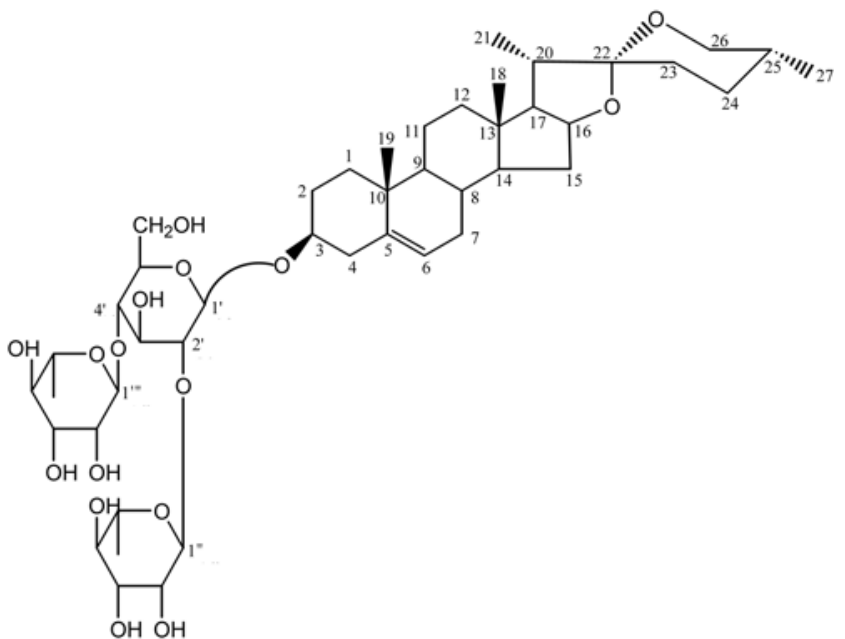

Fig. 1. The structure of dioscin.

\section{Materials and Methods}

Isolation of dioscin. Dioscoreae Rhizoma (DR) was collected from Kyeng-buk province (Korea) in August, 2000, and it was evaluated by Je-Hyun Lee, O.M.D., Ph.D. (Dongguk University, Gyeongju, Korea) prior to use. A voucher specimen (KIOM-02-3-0027) is stored in the Herbarium of the Korea Institute of Oriental Medicine (Daejeon, Korea). The dried DR $(5 \mathrm{~kg})$ were cut finely and percolated in methanol $(8 \mathrm{~L})$ at room temperature for 7 days and then filtered. The filtrate was concentrated under reduced pressure to give the methanol extract of DR $(200 \mathrm{~g})$. The methanol extract was solvent-extracted with n-hexane $(1.5 \mathrm{~L})$, EtOAc $(1.5 \mathrm{~L})$, and $n$ butanol $(1.5 \mathrm{~L})$ sequentially, 3 times each, and the solvent extracts were then filtered, evaporated, and lyophilized.

The dried n-butanol fraction $(78 \mathrm{~g})$ was sub-fractionated into 6 sub-fractions by silica gel column chromatography $(80 \mathrm{~cm} \times 10 \mathrm{~cm})$ with a $\mathrm{CHCl}_{3}$-methanol-water $(7: 3: 1$, lower part $6 \mathrm{~L})$ gradient system. Fraction 3 was further purified by column $(90 \mathrm{~cm} \times 3 \mathrm{~cm})$ chromatography with unsaturated EtOAc-MeOH $(98: 2,2 \mathrm{~L})$ followed by EtOAc-MeOH $(95: 5,2 \mathrm{~L})$ to isolate dioscin $(550 \mathrm{mg})$. The compound was further re-crystallized using methanol, to give a colorless, needle-shaped crystalline dioscin (Fig. 1) of the following structure (Wang et al., 2001):

Melting point: $289 \sim 292^{\circ} \mathrm{C}$;

$[\alpha]_{\mathrm{D}}^{25}:-110.5^{\circ}(c 0.3$ in $\mathrm{MeOH})$

IR $\left(\mathrm{KBr}, \mathrm{cm}^{-1}\right) 3420,1645,1100 \sim 1000,920,900,863,835$, (900>920, 25(R)-spiroketal), 810 FAB

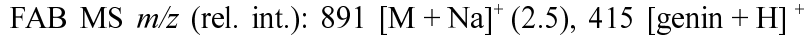

${ }^{1} \mathrm{H}$ NMR (300 MHz, pyridine- $\left.d_{5}\right)$ d: $0.68(3 \mathrm{H}, \mathrm{d}, J=5.2 \mathrm{~Hz}, 27-$ $\left.\mathrm{CH}_{3}\right) ; 0.82\left(3 \mathrm{H}, \mathrm{s}, 18-\mathrm{CH}_{3}\right) ; 1.05\left(3 \mathrm{H}, \mathrm{s}, 19-\mathrm{CH}_{3}\right) ; 1.12(3 \mathrm{H}, \mathrm{d}$, $\left.J=6.9 \mathrm{~Hz}, 21-\mathrm{CH}_{3}\right) ; 1.60\left(3 \mathrm{H}, \mathrm{d}, J=6.9 \mathrm{~Hz}, \mathrm{Rha}-\mathrm{CH}_{3}\right) ; 1.74(3 \mathrm{H}$, $\left.\mathrm{d}, J=6.2 \mathrm{~Hz}, \mathrm{Rha}-\mathrm{CH}_{3}\right) ; 4.92(1 \mathrm{H}, \mathrm{d}, J=6.7 \mathrm{~Hz}$, anomeric $\mathrm{H}$ of glucose); $5.32(1 \mathrm{H}$, br d, $J=4.6 \mathrm{~Hz}, \mathrm{H}-6) ; 5.80(1 \mathrm{H}, \mathrm{br} \mathrm{s}$, anomeric $\mathrm{H}$ of rhamnose); 6.34 (1H, br s, anomeric $\mathrm{H}$ of rhamnose).

${ }^{13} \mathrm{C}$ NMR (75.5 MHz, pyridine- $d_{5}$ ) d: 37.5 (C-1), 30.2 (C-2), 78.1 (C-3), 39.0 (C-4), 140.8 (C-5), 121.8 (C-6), 32.2 (C-7), 31.7 (C-8),
50.3 (C-9), 37.1 (C-10), 21.1 (C-11), 39.9 (C-12), 40.5 (C-13), 56.7 (C-14), 32.3 (C-15), 81.1 (C-16), 62.9 (C-17), 16.3 (C-18), 19.4 (C19), 42.0 (C-20), 15.0 (C-21), 109.3 (C-22), 31.8 (C-23), 29.3 (C24), 30.6 (C-25), 66.9 (C-26), 17.3 (C-27), 100.3 (C-1), 78.6 (C-2), 77.0 (C-3), 78.1 (C-4), 77.8 (C-5), 61.3 (C-6), 102.0 (C-1"), 72.6 (C-2"), 72.6 (C-3"), 74.1 (C-4"), 70.4 (C-5"), 18.5 (C-6"), 102.9 (C1), 72.8 (C-2), 72.9 (C-3), 73.9 (C-4), 69.5(C-5), 18.7 (C-6).

Rat pituitary cell culture. The pituitaries of Sprague-Dawley (SD) rats (3 to 4 weeks old; Daehan Biolink Co., Ltd.) were washed with a cold Hank's balanced salt solution (HBSS, pH 7.4, Gibco BRL.). They were then combined with $0.2 \%$ collagenase type IV (Gibco BRL.) and $0.2 \%$ hyaluronidase type III (Sigma Co.), and cultured at $37^{\circ} \mathrm{C}$ to isolate the pituitary cells (Kim et al., 2003; Jung et al., 2004). The isolated cells were centrifuged at $2,000 \mathrm{rpm}$ and the precipitates were washed with Dulbecco's Modified Eagle's medium (DMEM, Gibco BRL.) containing 10\% horse serum (Gibco BRL.), $2.5 \%$ fetal bovine serum (FBS, Gibco BRL.), and antibiotics (gentamicin and nystatin, Gibco BRL.). The cells were incubated under humidified conditions and a $5 \% \mathrm{CO}_{2}-95 \%$ air atmosphere at $37^{\circ} \mathrm{C}$ for $4 \sim 5$ days. The cultured cells were collected, washed with HBSS (pH 7.4) twice, and suspended at $7.5 \times 10^{4} \mathrm{cells} / \mathrm{ml}$. The suspended pituitary cells were combined with various concentrations $(0 \sim 1000 \mathrm{nM})$ of rGRF (Bachem Co.), as a positive control, and with the extracts (corresponding to $1 \mathrm{mg}$ of dried herb/ml), fractions $(20 \mu \mathrm{g} / \mathrm{ml})$, and dioscin $(5 \mu \mathrm{g} / \mathrm{ml})$ from DR. The cells were then incubated at $37^{\circ} \mathrm{C}$ for $15 \mathrm{~min}$. To determine the concentration dependency of dioscin, various dioscin concentrations $(0 \sim 10 \mu \mathrm{g} /$ $\mathrm{ml}$ ) were added to the pituitary cells, which were then incubated as described above. After incubation, the supernatant was collected and stored at $-70^{\circ} \mathrm{C}$ to determine the concentration of $\mathrm{GH}$; $\mathrm{GH}$ concentration was determined using an rGH RIA kit (Amersham).

Identification of the dioscin binding receptor. To identify whether the dioscin binding receptor is GHRH receptor (GRRH-R) or GHS-R, the pituitary cells were incubated with dioscin $\left(1.15 \times 10^{-5} \mathrm{M}\right)$ and human GHRH antagonist $\left(1 \times 10^{-6} \mathrm{M}\right.$ or $\left.1 \times 10^{-7} \mathrm{M}\right)$. The supernatants were collected to determine the concentrations of $\mathrm{rGH}$. At the same time, the pituitary cells were incubated with GHRP-6 antagonist $\left(1 \times 10^{-5} \mathrm{M}\right.$ or $\left.1 \times 10^{-6} \mathrm{M}\right)$, somatostatin-14 $\left(1 \times 10^{-5} \mathrm{M} \sim 1 \times 10^{-7} \mathrm{M}\right)$, and cyclo-somatostatin $\left(1 \times 10^{-5} \mathrm{M} \sim 1 \times 10^{-7} \mathrm{M}\right)$ as described above. The concentration of rGH released was determined using an rGH RIA kit (Amersham).

Induction of GH in SD rats. The SD rats (8 weeks old) were anesthetized with $50 \mathrm{mg} / \mathrm{kg}$ of pentobarbital (Hanlim Pharm. Co.) intraperitoneally, and then intravenously administered a saline solution containing $0.1 \% \mathrm{DMSO}$ and $10 \mu \mathrm{g} / \mathrm{kg}$ of dioscin through the jugular vein. The blood samples were collected from the tail vein at regular time intervals, centrifuged to isolate the plasma, and stored at $-70^{\circ} \mathrm{C}$. As a control group, select $\mathrm{SD}$ rats were intravenously administered $0.1 \%$ DMSO-containing saline only. Their plasma was collected after centrifugation and stored by the same procedure. The rGH levels in the plasma were determined using an rGH RIA kit.

Statistical analysis. The data are presented as mean \pm SEM, with statistical significance defined as $p<0.05$ by ANOVA or the 


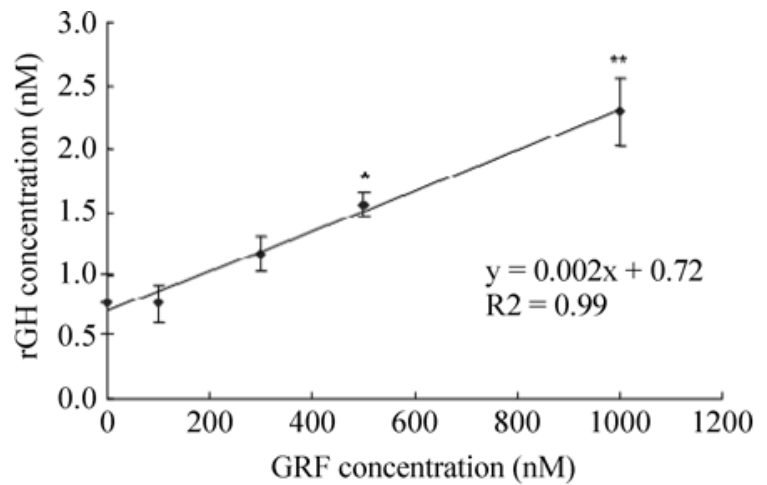

Fig. 2. rGH release by various concentrations of rGRF. Bars indicate standard errors of means $(\mathrm{SEM})(\mathrm{n}=9)$. The fitted standard curve of GRF on rGH release is $\mathrm{Y}=0.002 \mathrm{X}+0.72\left(\mathrm{R}^{2}=0.99\right)$. $\mathrm{Y}$ represents $\mathrm{rGH}$ concentration $(\mathrm{nM})$ and $\mathrm{X}$ represents $\mathrm{rGRF}$ concentration $(\mathrm{nM})$.

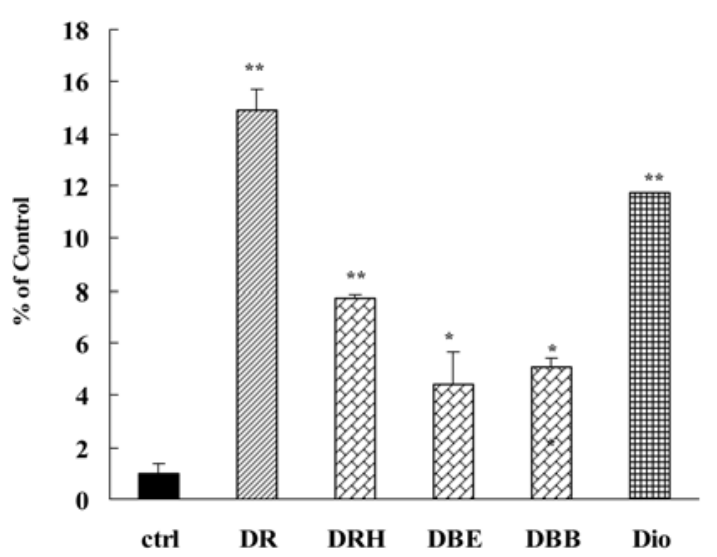

Fig. 3. Induction of $\mathrm{rGH}$ release by the medicinal herb $(1 \mathrm{mg} / \mathrm{ml})$, the fractions $(20 \mu \mathrm{g} / \mathrm{ml})$, and dioscin $(5 \mu \mathrm{g} / \mathrm{ml})$ on rat pituitary cells. Bars indicate standard errors of means (SEM) $(n=3)$. Ctrl: control, DR: Dioscoreae Rhizoma, DRH: n-hexane fraction of DR, DBE: EtOAc fraction of DR, DBB: BuOH fraction of DR, Dio: dioscin. ${ }^{*} p<0.05$ and ${ }^{* *} p<0.01$ as compared to the control by Bonferroni multiple comparisons.

Bonferroni Multiple comparison method (SYSTAT 10.0, SPSS Inc., USA).

\section{Results}

The correlation between rat GRF (rGRF) concentration and rGH level was analyzed by additions of various concentrations of rGRF (1-40) to the rat pituitary cells, in order to minimize experimental errors. The results show that GH release was GRF concentration-dependent (Fig. 2). To estimate the rGH releasing effect of DR, $1 \mathrm{mg}$ of dried herb/ml of DR methanol extract was added to the pituitary cells, and the concentration of released GH was determined (Fig. 3). The DR extract induced $\mathrm{rGH}$ release that was 15 -fold $(p<0.01)$ higher than

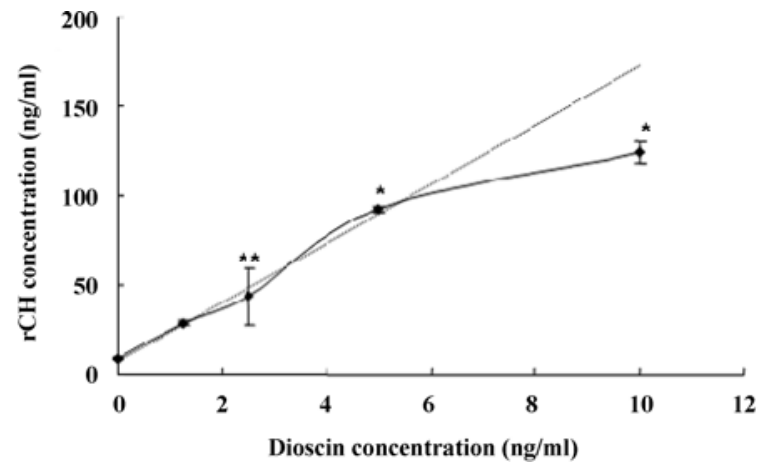

Fig. 4. rGH concentration $(\mathrm{ng} / \mathrm{ml})$ induced by various concentrations of dioscin $(\mathrm{ng} / \mathrm{ml})$. Bars indicate standard errors of means (SEM) $(\mathrm{n}=3) .{ }^{*} p<0.05$ and ${ }^{* *} p<0.01$ as compared to the control by Bonferroni multiple comparisons.

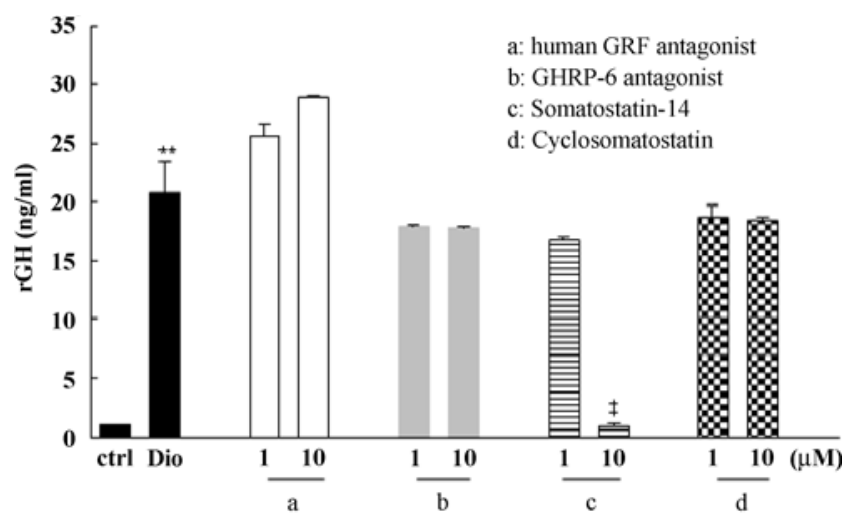

Fig. 5. Competitive inhibition of rGH release in the presence of dioscin $\left(1.15 \times 10^{-5} \mathrm{M}\right)$ by each addition of various concentrations of human GHRH antagonist, GHRP-6 antagonist, somatostatin-14, and cyclo-somatostatin. Bars indicate standard errors of means (SEM). The control group (ctrl) represents $\mathrm{rGH}$ release in the absence of dioscin, and Dio indicates that in the presence of dioscin. ${ }^{* *} p<0.01$ as compared to the control and $p<0.001$ as compared to the dioscin-only group by Bonferroni multiple comparisons.

that of the control $(0.36 \pm 0.02 \mathrm{nM})$. When the DR fractions were added to the pituitary cells $(20 \mu \mathrm{g} / \mathrm{ml})$, the $n$-hexane, EtOAc, and $\mathrm{BuOH}$ fractions induced $\mathrm{rGH}$ release that was 8fold $(2.76 \pm 0.29 \mathrm{nM})$, 4-fold $(1.59 \pm 0.05 \mathrm{nM})$, and 5 -fold $(1.81 \pm 0.43 \mathrm{nM})$ higher than the control $(0.36 \pm 0.02 \mathrm{nM})$, respectively ( $p<0.01$, Fig. 2$)$. Dioscin $(5 \mu \mathrm{g} / \mathrm{ml})$, a component of DR, induced rGH release at a level that was approximately 11-fold $(2.40 \pm 0.11 \mathrm{nM})$ higher than the control $(p<0.01)$ (Fig. 3). Additionally, we analyzed the induction on $\mathrm{rGH}$ release by using various concentrations of dioscin, and the results indicated that dioscin increased $\mathrm{rGH}$ release in a concentration-dependent manner. The $\mathrm{ED}_{50}$ value of dioscin calculated using the Michaelis-Menten's equation was $1.14 \times$ $10^{-5} \mathrm{M}$ (Fig. 4).

The effects of the antagonists on dioscin-induced rGH 


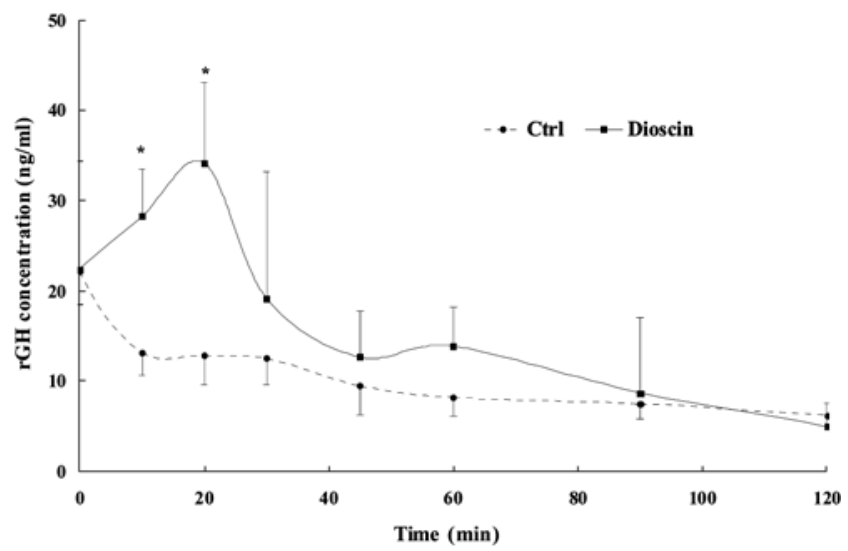

Fig. 6. Time course of released rGH concentration after intravenous administration of dioscin $(10 \mu \mathrm{g} / \mathrm{kg})$ in SD rats. Bars indicate standard errors of means (SEM). Ctrl $(n=27)$ represents the control group and dioscin $(\mathrm{n}=4)$ indicates the group with dioscin administraion. $\mathrm{t}_{\max }$ is $20 \mathrm{~min}$ after the dose. ${ }^{*} p<0.05$ and $* * p<0.01$ as compared to the control by ANOVA.

release are shown in Fig. 5. Incubating the pituitary cells with human GHRH antagonist or GHRH-6 antagonist $\left(1 \times 10^{-5} \mathrm{M}\right.$ and $\left.1 \times 10^{-6} \mathrm{M}\right)$ did not affect $\mathrm{rGH}$ release, but somatostatin$14\left(1 \times 10^{-5} \mathrm{M}\right)$ inhibited $\mathrm{rGH}$ induction to the basal level.

The induction effects of dioscin on $\mathrm{GH}$ release were evaluated in vivo, as described below. When dioscin was administered at $10 \mathrm{mg} / \mathrm{kg}$ intravenously, the $\mathrm{C}_{\max }$ of the $\mathrm{rGH}$ level in rat plasma $(34.16 \pm 14.10 \mathrm{ng} / \mathrm{ml})(\mathrm{n}=4)$ was approximately twice as high as in the control group (12.88 \pm $3.29 \mathrm{ng} / \mathrm{ml})(\mathrm{n}=27)(p<0.05$ at $20 \mathrm{~min}$ after the dose $)$ within $60 \mathrm{~min}$, and then the rGH level returned to the basal level within 90 min (Fig. 6).

\section{Discussion}

The concentration range of rGRF was used as a positive control to analyze the results (Fig. 2) and it showed that rGRF directly participates in GH release. In this report, the DR extract and its fractions resulted in 10-fold and 8- to 4-fold increases in the in vitro $\mathrm{rGH}$ concentration, respectively (Fig. $3)$. In general, there are many active compounds within the $\mathrm{MeOH}$ extract of herbs. Even though the $\mathrm{MeOH}$ extract showed the highest activity when compared to the negative control, the DBH, DBE, and DBB fractions showed lower activity than the $\mathrm{MeOH}$ extract. This may be attributed to the active compounds of the $\mathrm{MeOH}$ extract being divided into each fraction during fractionation, causing the fractions to show lower activity than the $\mathrm{MeOH}$ extract.

Consequently, the results demonstrate that the $\mathrm{MeOH}$ extract and its fractions have rGH release-inducing activity. Medicinal herbs are regarded as having excellent pharmaceutical efficacy and less adverse effects on humans, and their fractions and components like dioscin are easily obtained from the natural product.

It is known that $\mathrm{GH}$ prevents and cures various degenerative diseases, and GH release is reduced with aging. The GHS receptor (GHS-R) is expressed in the hypothalamus and pituitary gland, and it induces GH release by a mechanism that is different from that of GHRH. In this study, GH induction by dioscin may have been caused by direct action on the GHRH receptor (GHRH-R), because GH release was not inhibited by the human GHRH antagonist and GHRP-6 antagonist (Fig. 5). Further, GH induction by dioscin was inhibited by the addition of somatostatin-14 $\left(1 \times 10^{-5} \mathrm{M}\right)$, while cyclosomatostatin had no effect.

GHRP-6 has a lower induction of GH release than GRF, yet it is regarded as a useful synthetic peptide because it has a small molecular weight $(873.0 \mathrm{~g} / \mathrm{mol})$. The receptors, with which GH release inducing agents bind, are divided into the sub-groups of GHRH-R and GHS-R, and may have a synergistic effect on GH release according to their reaction mechanism. GHRH-R belongs to the G-protein receptor family and binds with G-proteins by a stimulus to activate cAMP. This increases cAMP and free $\mathrm{Ca}^{2+}$, which results in GH release. However, a synergistic effect on GH release by GHRH, GHS, and GHRP is recognized, yet they react independently (Bowers et al., 1990). This means that GHRH and GHRP have their own receptors. Previously, it was shown that the concentration of GH release increased 4.5-fold when GHRP-2 was administered to GH deficient (GHD) rats with mutated GHRH-Rs, while a normal group showed a 79-fold increase in its GH level. This demonstrates that GHRP-2 has a GHRH-independent effect on pituitary somatotroph cells, and an intact GHRH is necessary for the proliferation of normal somatotroph cells (Gondo et al., 2001).

To identify the dioscin binding receptor between GHRH-R and GHS-R, we added $\mathrm{ED}_{50}\left(1.14 \times 10^{-5} \mathrm{M}\right)$ of dioscin and a $1 \times 10^{-6} \mathrm{M}$ concentration each of human GHRH antagonist

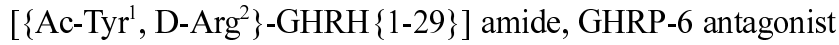
[ $\left\{\right.$ D-lys $\left.\left.{ }^{3}\right\}-G H R P-6\right]$, cyclosomatostatin [cyclo-7-aminoheptanoylPhe-D-Trp-Lys-Thr (BZL) acetate salt], and somatostatin-14 to the rat pituitary cells. The concentrations of $\mathrm{rGH}$ release by the treated cells were similar to that when only dioscin was added (Fig. 5). The rGH concentration, when $1 \times 10^{-5} \mathrm{M}$ GHRP-6 antagonist or cyclosomatostatin was added to the pituitary cells, was similar to that when dioscin alone was added. On the other hand, with the addition of $1 \times 10^{-5} \mathrm{M}$ somatostatin-14, rGH concentration was nearly $2.3 \%$ of that when only dioscin was added (Fig. 5). Consequently, it is assumed that the mechanism for dioscin is different from that of the human GHRH antagonist, GHRP-6 antagonist, and cyclosomatostatin, and that somatostatin-14 acts on the active site of dioscin as a competitive inhibitor. Therefore, dioscin is considered a clinically useful GH alternative that induces GH release by pituitary stimulation. Further study on its reaction mechanism is currently in progress.

We are studying the isolation and efficacy of compounds from all fractions. We initially found the efficacious component 
of the $\mathrm{BuOH}$ fraction, and presently, the $\mathrm{Hx}$ fraction is being studied for its effective compound.

Acknowledgments This research was supported by a grant (\# PF0321102-00) from the Plant Diversity Research Center of the 21st Century Frontier Research Program, which is funded by the Korean government's Ministry of Science and Technology.

\section{References}

Argente, J., Pozo, J. and Chowen, J. A. (1996) The growth hormone axis: control and effects. Horm. Res. 45 (S 1), 9-11.

Au, A. L. H., Kwok, C. C., Lee, A. T. C. and Kwan, Y. W. (2004) Activation of iberiotoxin-sensitive, $\mathrm{Ca}+$-activated $\mathrm{K}+$ channels of porcine isolated left anterior descending coronary artery by diosgenin. Eur. J. Pharmacol. 502, 123-133.

Bowers, C. Y., Reynolds, G. A., Chang, D., Hong, A., Chang, K. and Momany, F. (1981) A study on the regulation of growth hormone release from the pituitaries of rats in vitro. Endocrinology 108, 1071-1080.

Bowers, C. Y., Momany, F. A., Reynolds, G. A. and Hong, A. (1984) On the in vitro and in vivo activity of a new synthetic hexapeptide that acts on the pituitary to specifically release growth hormone. Endocrinology 114, 1537-1545.

Bowers, C. Y., Reynolds, G. A., Durham, D., Barrera, C. M., Pezzoli, S. S. and Thorner, M. O. (1990) Growth hormone (GH)-releasing peptide stimulates $\mathrm{GH}$ release in normal men and acts synergistically with GH-releasing hormone. J. Clin. Endocrinol. Metab. 70, 975-982.

Brakohiapa, L. A., Quaye, I. K., Amoah, A. G., Harrison, E. K., Kennedy, D., Kido, Y. and Ofei, F. (1997) Blood glucose responses to mixed Ghanaian diets in healthy adult males. West. Afr. J. Med. 16, 170-173.

Cheng, K., Chan, W. W., Butler, B., Wei, L. and Smith, R. G. (1993) A novel non-peptidyl growth hormone secretagogue. Horm. Res. 40, 109-115.

Chiang, H. C., Wang, J. J. and Wu, R. T. (1992) Immuno-modulating effects of the hydrolysis products of formosanin $\mathrm{C}$ and betaecdysone from Paris formosana Hayata. Anticancer Res. 12, 1475-1478.

Choi, E. M. and Hwang, J. K. (2002) Enhancement of oxidative response and cytokine production by yam mucopolysaccharide in murine peritoneal macrophage. Fitoterapia 73, 629-637.

Choi, E. M., Koo, S. J. and Hwang, J. K. (2003) Immune cell stimulating activity of mucopolysaccharide isolated from yam (Dioscorea batatas). J. Ethnopharmacol. 91, 1-6.

Farombi, E. O., Britton, G. and Emerole, G. O. (1999) Evaluation of the antioxidant activity and partial characterization of extracts from browned yam flour diet. Food Res. Int. 33, 493-499.

Gondo, R. G., Aguiar-Oliveira, M. H., Hayashida, C. Y., Toledo, S.
P., Abelin, N., Levine, M. A., Bowers, C. Y., Souza, A. H., Pereira, R. M., Santos, N. L. and Salvatori, R. (2001) Growth hormone-releasing peptide- 2 stimulates $\mathrm{GH}$ secretion in GHdeficient patients with mutated GH-releasing hormone receptor. $J$. Clin. Endocrinol. Metab. 86, 3279-3283.

Horber, F. F. and Haymond, M. W. (1990) Human growth hormone prevents the protein catabolic side effects of prednisone in humans. J. Clin. Invest. 86, 265-272.

Hu, K., Dong, A., Yao, X., Kobayashi, H. and Iwasaki, S. (1996) Antineoplastic agents; I. Three spirostanol glycosides from rhizomes of Dioscorea collettii var. hypoglauca. Planta Med. 62, 573-575.

Jung, D. Y., Ha, H. and Kim, C. (2004) Indcution of gorwth hormone release by Pueraria thunbergiana B. Horm. Metab. Res. 36, 8691.

Kim, C., Ha, H., Kim, J. S., Kim, Y. T., Kwon, S. C. and Park, S. W. (2003) Induction of growth hormone by the roots of Astragalus membranaceus in pituitary cell culture. Arch. Pharm. Res. 26, 3439.

Kim, S. W., Chung, K. C., Son, K. H. and Kang, S. S. (1989) Steroidal saponins from the Rhizomes of Smilax china. Kor. $J$. Pharmacogn. 20, 76-82.

Kojima, M., Hosoda, H., Date, Y., Nakazato, M., Matsuo, H. and Kangawa, K. (1999) Ghrelin is a growth-hormone-releasing acylated peptide from stomach. Nature 402, 656-660.

Momany, F. and Bowers, C. Y. (1996) Computer-assisted modeling of xenobiotic growth hormone secretaogues; in Growth hormone Secretagogues, Bercu B, Walker R (eds.), pp. 73-83, New York: Springer-Verlag, New York, USA.

Morrison, E. Y., Ragoobirsingh, D. and Peter, S. A. (2006) The Unitarian hupothesis for the aetiology of diabetes mellitus. Med. Hypotheses 67, 1115-1120.

Patchett, A. A., Nargund, R. P., Tata, J. R., Chen, M. H., Barakat, K. J., Johnston, D. B., Cheng, K., Chan, W. W., Butler, B. and Hickey, G. (1995) Design and biological activities of L-163,191 (MK-0677): a potent, orally active growth hormone secretagogue. Proc. Natl. Acad. Sci. USA 92, 7001-7005.

Sata, N., Matsunaga, S., Fusetani, N., Nishikawa, H., Takamura, S. and Saito, T. (1998) New antifungal and cytotoxic steroidal saponins from the bulbs of an elephant garlic mutant. Biosci. Biotechnol. Biochem. 62, 1904-1911.

Sliutz, G., Speiser, P., Schultz, A. M., Spona, J. and Zeillinger, R. (1993) Agnus castus extracts inhibit prolactin secretion of rat pituitary cells. Horm. Metab. Res. 25, 253-255.

Smith, R. G., Cheng, K., Schoen, W. R., Pon, S. S., Hichey, J., Jacks, T., Butler, B., Chan, W. W. S., Chaung, L. Y. P., Judith, F., Talor, J., Wyvratt, M. J. and Fisher, M. H. (1993) A novel nonpeptidyl growth hormone secretagogue. Science 260, 1640-1643.

Wang, Z., Zhou, J., Ju, Y., Zhang, H., Liu, M. and Li, X. (2001) Effects of two saponins extracted from the polygonatum Zanlanscianense pamp on the human leukemia (HL-60) cells. Biol. Pharm. Bull. 24, 159-162. 